\title{
Experimental verification of two-parametic models of fatigue characteristics by using the tests of S55J0 steel as an example
}

\author{
Bogdan Ligaj, Ph. D. \\ Grzegorz Szala, Ph. D. \\ University of Technology and Life Science, Bydgoszcz
}

\begin{abstract}
This paper presents experimental verification of models of two-parametric fatigue characteristics $N\left(\sigma_{a}, \sigma_{m}\right)$ on the basis of results of fatigue tests of specimens made of S355J0 steel. On the basis of comparative analysis of results of computations and fatigue life tests of the specimens, performed under constant amplitude sinusoidal loads of different cycle asymmetry ratios, the most versatile models were distinguished. The tests in question were carried out in the high-cycle fatigue range.
\end{abstract}

Keywords: two-parametic models, fatigue characteristics, tests of S55J0 steel, computations, fatigue life tests, high-cycle fatigue range

\section{INTRODUCTION}

Random loads commonly occur in service conditions of machines and devices including sea-going ships, ocean engineering objects, land road vehicles, aircrafts, heavy machines etc. From the point of view of mathematical theory of stochastic processes operational loads are non-stationary stochastic processes $[1,2]$, that makes direct application of the theory in question to calculating fatigue life of structural elements, difficult.

In practice fatigue life of structural elements is calculated in accordance with the schematic diagram shown in Fig. 1. As results from it, the following should be known to carry out fatigue calculations: service load spectrum and fatigue characteristics, as well as to assume an appropriate hypothesis of cumulating fatigue damage [3].

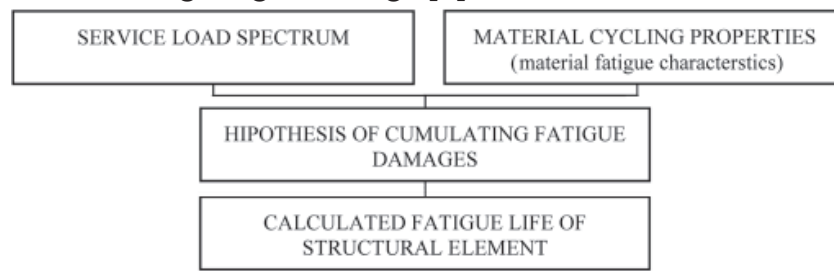

Fig. 1. Schematic diagram of calculation process of structural element fatigue life

In fatigue life calculations random run of service loads is usually substituted by a set of sinusoidal cycles determined in accordance with appropriate methods [4]. Their spectra can be described by means of distribution of load amplitude substitute values as in the case of broad-band random loads -by distribution of $S_{a}$ - amplitude values and $S_{m}$ - mean values of cycles or $\mathrm{S}_{\min }$ - minimum values and $\mathrm{S}_{\text {max }}$ - maximum values. Fig. 2 shows a scheme of possible cases of sinusoidal cycles having dif ferent parameters. The sinusoidal cycle is unambiguously described by the following parameters: $\mathrm{S}$ $\mathrm{S}_{\max }, \mathrm{f}=1 / \mathrm{T}$, or $\mathrm{S}_{\mathrm{a}}, \mathrm{S}_{\mathrm{m}}, \mathrm{f}$.

Influence of the load frequency f on fatigue life of structural elements is usually low and neglected in calculations of many elements. Location of a load cycle within the reference system $\left(\mathrm{S}_{\min }, \mathrm{S}_{\max }\right)$ or $\left(\mathrm{S}_{\mathrm{a}}, \mathrm{S}_{\mathrm{m}}\right)$ is determined by the cycle asymmetry ratio $\mathrm{R}=\mathrm{S}{ }_{\min } / \mathrm{S}_{\max }$, or sometimes - the load steadiness ratio $\chi=\mathrm{S}_{\mathrm{m}} / \mathrm{S}_{\mathrm{a}}$.

Load spectra are then elaborated in one of the two reference systems: $\left(\mathrm{S}_{\min }, \mathrm{S}_{\max }\right)$ [5] or $\left(\mathrm{S}_{\mathrm{a}}, \mathrm{S}_{\mathrm{m}}\right)[4,6]$. In such cases appropriate fatigue characteristics is that characterized by two parameters: $\mathrm{N}\left(\mathrm{S}_{\mathrm{a}}, \mathrm{S}_{\mathrm{m}}\right)$ or $\mathrm{N}\left(\mathrm{S}_{\min }, \mathrm{S}_{\max }\right)$.

In this paper the problem is discussed of experimental verification of selected two-parametric fatigue characteristics, performed on the basis of test results of specimens made of S355J0 steel.

\section{DESCRIPTION OF SELECTED TWO-PARAMETRIC FATIGUE CHARACTERISTICS}

Concept of description of limit stress diagrams (fatigue limit range) with taking into account mean value of cycle amplitude was presented in [7]. The descriptions of range of limited fatigue life were presented in $[8,9,10,11,12,13]$.

In Tab. 1 are collected the formulae describing the above mentioned characteristics together with references to their 


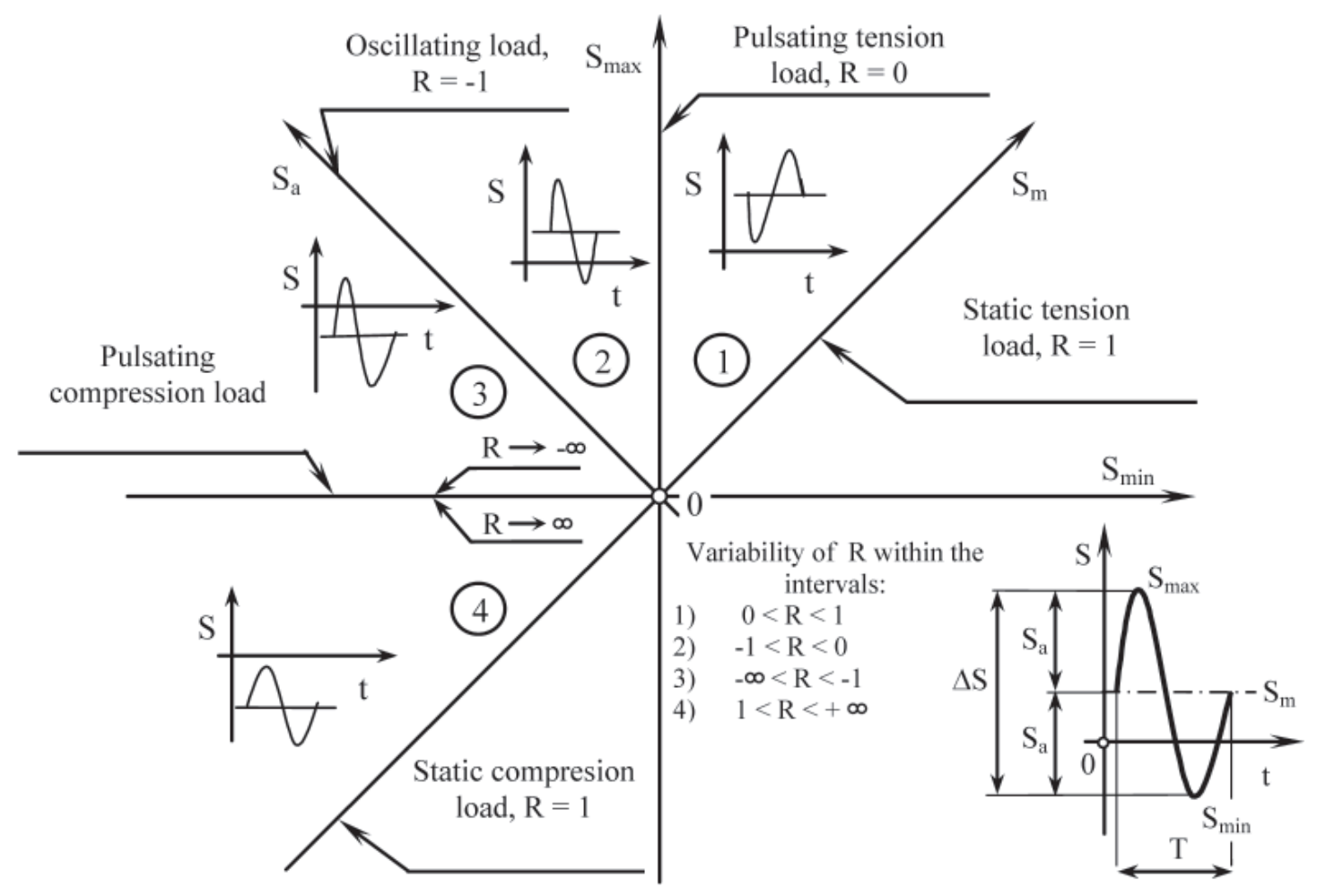

Fig. 2. Plane of variability of sinusoidal load parameters

literature sources. The formulae (4), (5) and (10) concern description of limit stresses within the range of fatigue limit called also the unlimited fatigue life $(\mathrm{FL})(\mathrm{N} \rightarrow \infty)$ for steel. In practice it is assumed that it concerns the cycle number $\mathrm{N}>\mathrm{N}$ and $\mathrm{N}_{0}$ is the cycle number corresponding with the slope change point on Wöhler fatigue diagram. The remaining formulae: (1), (2), (6), (7), (8), (9), (11) and (12) deal with description within the high-cycle fatigue range (HCF), called also the limited fatigue life. The range is described by the conditions:

$\mathrm{S}_{\max }=\mathrm{S}_{\mathrm{a}}+\mathrm{S}_{\mathrm{m}}<\mathrm{R}_{\mathrm{m}}$ - for elastic-brittle materials

$\mathrm{S}_{\max }=\mathrm{S}_{\mathrm{a}}+\mathrm{S}_{\mathrm{m}} \leq \mathrm{R}_{\mathrm{e}} \quad$ - for elastic-plastic materials.

In the first three positions of Tab 1. are given the relations corresponding with limit stress diagrams in the reference system $\left(\mathrm{S}_{\mathrm{m}}, \mathrm{S}_{\mathrm{a}}\right)$ for unlimited fatigue life $(\mathrm{N} \rightarrow \infty)$. The simplest form of Goodman's relation, i.e. the formula (1), corresponds with straight line in the above mentioned reference system. Gerber 's limit stress diagram, i.e. the formula (2), is of parabolic form. Haighs' diagram, i.e. the formula (3), is based on elliptic relationship.

The two-parametric fatigue characteristics analyzed in this paper constitute a generalized form of the above mentioned relations used for description of limit stress diagrams in the range of high-cycle fatigue (HCF), i.e. the limited fatigue life range. The relations are here shortly called models.The oldest is Heywood's model $(\mathrm{H})$ described in the subject-matter literature $[4,8]$, which is used, in this paper, for comparision with the remaining models. The model I, an expanded form of Haigh's relation, consists of two straight line sections; the first of them corresponds with the variability range of the cycle asymmetry ratio $\mathrm{R}$ between 0 and 1 , the second - between 0 and $-\infty$.
The diagram in the broken-line form crosses the three points: $\left(\mathrm{S}_{\mathrm{a}}=0 ; \mathrm{R}_{\mathrm{m}}\right.$ or $\left.\mathrm{R}_{\mathrm{e}}\right),\left(1 / 2 \mathrm{R}_{0}^{\mathrm{N}} ; 1 / 2 \mathrm{R}_{0}^{\mathrm{N}}\right)$ and $\left(\mathrm{S}_{\mathrm{m}}=0 ; \mathrm{R}_{-}^{\mathrm{N}}\right)$. The model II, a generalized form of Goodmans̉ relation, covers, by single relation, the variability range of $\mathrm{R}$ from 1 to $-\infty$. The diagram lines of the model cross the two points: $\left(\mathrm{S}_{\mathrm{a}}=0 ; \mathrm{R}_{\mathrm{m}}\right.$ or $\left.\mathrm{R}_{\mathrm{e}}\right)$ and $\left(\mathrm{S}_{\mathrm{m}}=0 ; \mathrm{R}_{-1}^{\mathrm{N}}\right)$.

The model III is an expansion of Gerber 's relation [the formula (2)], and the model IV is an expansion of Haigh' $s$ relation [the formula (3)]. In both the above mentioned models the diagram lines cross the points: $\left(\mathrm{S}_{\mathrm{a}}=0 ; \mathrm{R}_{\mathrm{m}}\right.$ or $\left.\mathrm{R}_{\mathrm{e}}\right)$ and $\left(\mathrm{S}_{\mathrm{m}}=0 ; \mathrm{R}_{-1}^{\mathrm{N}}\right)$.

The model V which connects features of the models: H, I and III, is based on parabolic relation where the parable crosses the three characteristic points as in the model I.

The last model, acc. Bołotin, is a transformation of the model I into the reference system $\left(\mathrm{S}_{\min }, \mathrm{S}_{\max }\right)$ and hence it has been not subjected to any detail analysis.

\section{EXAMPLE TWO-PARAMETRIC FATIGUE CHARACTERISTICS FOR S355J0 STEEL}

Strength properties of S355J0 steel under monotonicloads is given in Tab. 2, and its cyclic properties - in Tab. 3 .

Tab. 2. Static strength properties of S355J0 steel

\begin{tabular}{|c|c|c|c|c|c|}
\hline \multirow{2}{*}{} & \multicolumn{4}{|c|}{ Static properties of S355J0 steel } \\
\cline { 2 - 6 } & $\begin{array}{c}\mathbf{R}_{\mathrm{e}} \\
{[\mathbf{M P a}]}\end{array}$ & $\begin{array}{c}\mathbf{R}_{\mathbf{m}} \\
{[\mathbf{M P a}]}\end{array}$ & $\begin{array}{c}\mathbf{E} \\
{[\mathbf{M P a}]}\end{array}$ & $\begin{array}{c}\mathbf{A}_{\mathbf{5}} \\
{[\mathbf{\%}]}\end{array}$ & $\begin{array}{c}\mathbf{Z} \\
\mathbf{\%}]\end{array}$ \\
\hline Mean value & 499.9 & 678.0 & 208159 & 17.2 & 59.8 \\
\hline Standard deviation & 8.4 & 7.1 & 1306 & 0.99 & 0.9 \\
\hline
\end{tabular}

Tab. 3. Cyclic mechanical strength properties of S355J0 steel

\begin{tabular}{|c|c|c|c|c|c|}
\hline \multirow{2}{*}{ Type of load } & \multirow{2}{*}{$\begin{array}{c}\text { Equation } \\
\text { form }\end{array}$} & \multirow{2}{*}{ Exponent } & \multirow{2}{*}{ Free term } & \multicolumn{2}{|c|}{ Fatigue limit } \\
\cline { 4 - 6 } & & & $\mathbf{R}_{\mathbf{f}}$ & $\mathbf{N}_{\mathbf{0}}$ \\
\hline Oscillating load $(\mathbf{R}=\mathbf{- 1})$ & $\mathrm{S}_{\mathrm{a}}^{\mathrm{m}_{0}} \cdot \mathrm{N}=\mathrm{C}_{0}$ & $\mathrm{~m}_{0}=12.33$ & $\mathrm{C}_{0}=1.156 \cdot 10^{36}$ & $\mathrm{R}_{1}=274$ & $10^{6}$ \\
\hline Pulsating load $(\mathbf{R}=\mathbf{0})$ & $\mathrm{S}_{\max }^{\mathrm{m}_{0}} \cdot \mathrm{N}=\mathrm{C}$ & $\mathrm{m}=15.92$ & $\mathrm{C}=6.163 \cdot 10^{48}$ & $\mathrm{R}_{0}=480$ & $10^{6}$ \\
\hline
\end{tabular}


Tab. 1. Collection of the formulae which describe fatigue characteristics

\begin{tabular}{|c|c|c|c|c|}
\hline No. & Name and form of formula & & $\begin{array}{c}\text { Application range } \\
\text { Variability range } \mathrm{R}\end{array}$ & $\begin{array}{c}\text { Literat. } \\
\text { source }\end{array}$ \\
\hline 1 & 2 & & 3 & 4 \\
\hline 1. & $\begin{array}{l}\frac{\mathrm{S}_{\mathrm{a}}}{\mathrm{R}_{-1}}+\frac{\mathrm{S}_{\mathrm{m}}}{\mathrm{R}_{\mathrm{m}}}=1 \\
\text { Fatigue diagram acc. Goodman }\end{array}$ & (1) & $\begin{array}{c}\text { Range of fatigue limit } \\
\text { (FL) } \\
\mathrm{S}_{\mathrm{az}} \leq \mathrm{R}_{-1}\end{array}$ & [14] \\
\hline 2. & $\frac{\mathrm{S}_{\mathrm{a}}}{\mathrm{R}_{-1}}+\left(\frac{\mathrm{S}_{\mathrm{m}}}{\mathrm{R}_{\mathrm{m}}}\right)^{2}=1$ & (2) & $\begin{array}{c}\text { Range of fatigue limit FL } \\
\text { FL } \\
\mathrm{S}_{\mathrm{az}} \leq \mathrm{R}_{-1}\end{array}$ & [7] \\
\hline 3. & $\begin{array}{l}\text { Fatigue diagram acc. Haigh } \\
\left(\frac{\mathrm{S}_{\mathrm{a}}}{\mathrm{R}_{-1}}\right)^{2}+\left(\frac{\mathrm{S}_{\mathrm{m}}}{\mathrm{R}_{\mathrm{m}}}\right)^{2}=1\end{array}$ & (3) & $\begin{array}{c}\text { Range of fatigue limit FL } \\
\text { FL } \\
-\infty<\mathrm{R} \leq 1.0\end{array}$ & [14] \\
\hline 4. & $\begin{array}{l}\frac{\mathrm{S}_{\mathrm{a}}}{\mathrm{R}_{\mathrm{m}}}=\left(1-\frac{\mathrm{S}_{\mathrm{m}}}{\mathrm{R}_{\mathrm{m}}}\right)\left[\mathrm{A}_{0}+\gamma\left(1-\mathrm{A}_{0}\right)\right] \\
\text { where: } \mathrm{A}_{0} \text { and } \gamma-\text { constants determined with the use of sm } \\
\text { specimens: } \\
\quad \gamma=\frac{\mathrm{S}_{\mathrm{m}}}{3 \mathrm{R}_{\mathrm{m}}}\left(2+\frac{\mathrm{S}_{\mathrm{m}}}{\mathrm{R}_{\mathrm{m}}}\right), \mathrm{A}_{0}=\frac{1+0.0038(\log \mathrm{N})^{4}}{1+0.008(\log \mathrm{N})^{4}} \\
\quad-\text { for Al alloys: } \\
\gamma=\frac{1+\frac{0.0031(\log \mathrm{N})^{4}}{1+0.003(\log \mathrm{N})^{4}}}{1+0.0031(\log \mathrm{N})^{4}} \\
\mathrm{R}_{\mathrm{m}}\left[1+\frac{\mathrm{S}_{\mathrm{m}}(\log \mathrm{N})^{4}}{225}\right]\end{array}$ & lut) & $\begin{array}{c}\text { Range of HCF for: } \\
\text { - brittle materials } \\
\mathrm{S}_{\max }=\mathrm{S}_{\mathrm{a}}+\mathrm{S}_{\mathrm{m}} \leq \mathrm{R}_{\mathrm{m}} \\
\text { - elastic-plastic materials } \\
\mathrm{S}_{\max }=\mathrm{S}_{\mathrm{a}}+\mathrm{S}_{\mathrm{m}} \leq \mathrm{R}_{\mathrm{c}} \\
-\infty<\mathrm{R}<1.0\end{array}$ & [4] \\
\hline 5. & $\begin{array}{l}\mathrm{N}=\frac{\mathrm{N}_{0} \mathrm{R}_{-1}^{\mathrm{m}_{0}}}{\left(\mathrm{~S}_{\mathrm{a}}+\psi_{\mathrm{N}} \mathrm{S}_{\mathrm{m}}\right)^{\mathrm{m}_{0}}} \\
\mathrm{~N}=\mathrm{N}_{0}\left[\frac{\mathrm{R}_{-1}\left(\mathrm{R}_{\mathrm{m}}+\mathrm{S}_{\mathrm{a}}-\mathrm{S}_{\mathrm{m}}\right)}{\mathrm{S}_{\mathrm{a}} \mathrm{R}_{\mathrm{m}}\left(1+\psi_{\mathrm{N}}\right)}\right]^{\mathrm{m}_{0}} \\
\frac{\psi_{\mathrm{N}}=2 \mathrm{C}_{0}^{\frac{1}{\mathrm{~m}_{0}}} \mathrm{C}^{-\frac{1}{\mathrm{~m}}} \mathrm{~N}^{\left.\frac{1}{\mathrm{~m}}-\frac{1}{\mathrm{~m}_{0}}\right)}-1}{\mathrm{~S}_{\mathrm{m}}}=-\psi_{\mathrm{N}} \frac{\mathrm{S}_{\mathrm{m}}}{\mathrm{R}_{\mathrm{m}}}+\frac{\mathrm{R}_{-1}}{\mathrm{R}_{\mathrm{m}}}\left(\frac{\mathrm{N}_{0}}{\mathrm{~N}}\right)^{\frac{1}{\mathrm{~m}_{0}}} \\
\frac{\mathrm{S}_{\mathrm{a}}}{\mathrm{R}_{\mathrm{m}}}=\frac{\mathrm{R}_{-1}}{\mathrm{R}_{\mathrm{m}}\left(\frac{\mathrm{N}}{\mathrm{N}_{0}}\right)^{\frac{1}{\mathrm{~m}_{0}}}\left(1+\psi_{\mathrm{N}}\right)-\mathrm{R}_{-1}}\end{array}$ & (6a) & $\begin{array}{c}\text { Range of HCF: } \\
-\infty<\mathrm{R} \leq 0 \\
0<\mathrm{R} \leq 1.0\end{array}$ & [12] \\
\hline
\end{tabular}


Tab. 1. Collection of the formulae which describe fatigue characteristics

\begin{tabular}{|c|c|c|c|}
\hline No. & Name and form of formula & $\begin{array}{c}\text { Application range } \\
\text { Variability range } \mathrm{R}\end{array}$ & $\begin{array}{l}\text { Literat. } \\
\text { source }\end{array}$ \\
\hline 1 & 2 & 3 & 4 \\
\hline 7. & $\begin{array}{l}\text { Fatigue diagram acc. Lipski (the model III) } \\
\mathrm{N}=\mathrm{N}_{0}\left[\frac{\mathrm{R}_{-1}}{\mathrm{~S}_{\mathrm{a}}}\left(1-\left(\frac{\mathrm{S}_{\mathrm{m}}}{\mathrm{R}_{\mathrm{m}}}\right)^{2}\right)\right]^{\mathrm{m}_{0}} \\
\frac{\mathrm{S}_{\mathrm{a}}}{\mathrm{R}_{\mathrm{m}}}=\frac{\mathrm{R}_{-1}}{\mathrm{R}_{\mathrm{m}}}\left(\frac{\mathrm{N}_{0}}{\mathrm{~N}}\right)^{\frac{1}{\mathrm{~m}_{0}}}\left[1-\left(\frac{\mathrm{S}_{\mathrm{m}}}{\mathrm{R}_{\mathrm{m}}}\right)^{2}\right]\end{array}$ & $\begin{array}{l}\text { Range of HCF: } \\
-\infty<\mathrm{R} \leq 1.0\end{array}$ & [12] \\
\hline 8. & $\begin{array}{l}\text { Fatigue diagram acc. Lipski (the model IV) } \\
\mathrm{N}=\mathrm{N}_{0}\left[\frac{\mathrm{R}_{-1}}{\mathrm{~S}_{\mathrm{a}}} \sqrt{1-\left(\frac{\mathrm{S}_{\mathrm{m}}}{\mathrm{R}_{\mathrm{m}}}\right)^{2}}\right]^{\mathrm{m}_{0}} \\
\frac{\mathrm{S}_{\mathrm{a}}}{\mathrm{R}_{\mathrm{m}}}=\frac{\mathrm{R}_{-1}}{\mathrm{R}_{\mathrm{m}}}\left(\frac{\mathrm{N}_{0}}{\mathrm{~N}}\right)^{\frac{1}{\mathrm{~m}_{0}}} \sqrt{1-\left(\frac{\mathrm{S}_{\mathrm{m}}}{\mathrm{R}_{\mathrm{m}}}\right)^{2}}\end{array}$ & $\begin{array}{l}\text { Range of HCF: } \\
-\infty<\mathrm{R} \leq 1.0\end{array}$ & [12] \\
\hline 9. & $\begin{array}{l}\text { Fatigue diagram acc. Lipski (the model V) } \\
\frac{\mathrm{S}_{\mathrm{a}}}{\mathrm{R}_{\mathrm{m}}}=\mathrm{a}_{1}\left(\frac{\mathrm{S}_{\mathrm{m}}}{\mathrm{R}_{\mathrm{m}}}\right)^{2}+\mathrm{a}_{2} \frac{\mathrm{S}_{\mathrm{m}}}{\mathrm{R}_{\mathrm{m}}}+\left(\frac{\mathrm{C}_{0}}{\mathrm{~N}}\right)^{\frac{1}{\mathrm{~m}_{0}}} \mathrm{R}_{\mathrm{m}}^{-1} \\
\mathrm{a}_{1}=2 \mathrm{R}_{\mathrm{m}}\left[\left(\frac{\mathrm{C}}{\mathrm{N}}\right)^{\frac{1}{\mathrm{~m}}}\left(1-\mathrm{a}_{2}\right)-2\left(\frac{\mathrm{C}_{0}}{\mathrm{~N}}\right)^{\frac{1}{\mathrm{~m}_{0}}}\right]\left(\frac{\mathrm{C}_{0}}{\mathrm{~N}}\right)^{-\frac{2}{\mathrm{~m}_{0}}} \\
\mathrm{a}_{2}=\frac{4 \mathrm{R}_{\mathrm{m}}^{2}\left(\frac{\mathrm{C}_{0}}{\mathrm{~N}}\right)^{\frac{1}{\mathrm{~m}_{0}}}-\left(\frac{\mathrm{C}}{\mathrm{N}}\right)^{\frac{1}{\mathrm{~m}}}\left[2 \mathrm{R}_{\mathrm{m}}^{2}+\left(\frac{\mathrm{C}_{0}}{\mathrm{~N}}\right)^{\frac{1}{\mathrm{~m}_{0}}}\left(\frac{\mathrm{C}}{\mathrm{N}}\right)^{\left.\frac{1}{\mathrm{~m}}\right]}\right.}{\mathrm{R}_{\mathrm{m}}\left[\left(\frac{\mathrm{C}}{\mathrm{N}}\right)^{\frac{1}{\mathrm{~m}}}-2 \mathrm{R}_{\mathrm{m}}\right]\left(\frac{\mathrm{C}}{\mathrm{N}}\right)^{\frac{1}{\mathrm{~m}}}}\end{array}$ & $\begin{array}{l}\text { Range of HCF: } \\
-\infty<\mathrm{R} \leq 1.0\end{array}$ & [12] \\
\hline 10. & $\begin{aligned} & \mathrm{N}= \frac{2^{\mathrm{m}_{0}} \mathrm{~N}_{0} \mathrm{R}_{-1}^{\mathrm{m}_{0}}}{\left[(1+\psi) \mathrm{S}_{\max }-(1-\psi) \mathrm{S}_{\min }\right]^{\mathrm{m}_{0}}} \\
& \mathrm{~N}= \frac{2^{\mathrm{m}_{0}} \mathrm{~N}_{0} \mathrm{R}_{-1}^{\mathrm{m}_{0}}}{\left[\left(1-\psi^{\prime}\right) \mathrm{S}_{\max }-\left(1+\psi^{\prime}\right) \mathrm{S}_{\min }\right]^{\mathrm{m}_{0}}} \\
& \quad \text { where: } \psi \text { and } \psi^{\prime} \text { - material constants } \\
& \text { (factors of material sensitivity to cycle asymmetry) }\end{aligned}$ & $\begin{array}{l}\text { Range of HCF: } \\
\text { for } \\
\mathrm{S}_{\max }+\mathrm{S}_{\min } \geq 0 \\
\quad \text { for } \\
\mathrm{S}_{\max }+\mathrm{S}_{\min }<0\end{array}$ & [13] \\
\hline \multicolumn{4}{|c|}{$\begin{array}{r}\text { Comments and basic formulae: } \\
\text { Wöhler diagram for } \mathrm{R}=-1: \\
\text { - general form: } \mathrm{S}_{\mathrm{a}}^{\mathrm{m}_{0}} \cdot \mathrm{N}=\mathrm{C}_{0} \\
\text { - logarithmic form: } \log \mathrm{S}_{\mathrm{a}}=-\frac{1}{\mathrm{~m}_{0}} \log \mathrm{N}+ \\
\text { Wöhler diagram for } \mathrm{R}=0 \text { : } \\
\text { - general form: } \mathrm{S}_{\max }^{m_{0}} \cdot \mathrm{N}=\mathrm{C} \\
\text { - logarithmic form: } \log \mathrm{S}_{\max }=-\frac{1}{\mathrm{~m}} \log \mathrm{N} \\
\text { cycle asymmetry ratio: } \mathrm{R}=\frac{\mathrm{S}_{\min }}{\mathrm{S}_{\max }}=\frac{\left(\mathrm{S}_{\mathrm{m}}\right.}{\left(\mathrm{S}_{\mathrm{m}}\right.}\end{array}$} \\
\hline
\end{tabular}


Knowledge of mechanical properties of S355J0 steel makes it possible to determine two-parametric fatigue characteristics complying with the models presented in Tab. 1. The models specified in items: $1,5,6,7,9$ and 10 have been taken into consideration for further analyses.

\section{Heywood's model}

The Heywood's model (item. 4, Tab. 1) was selected to exemplify a way of determining two-parametric fatigue characteristics, their graphical form and characteristic features of diagrams. Such diagrams are elaborated in the reference system $\left(\mathrm{S}_{\mathrm{m}}, \mathrm{S}_{\mathrm{a}}\right)$, in the form of contour line diagramsParticular contour lines are of constant fatigue life N. Hence when an appropriate value $\mathrm{N}$ is assumed a corresponding contour line can be determined on the basis of the formulae (4) by calculating $\mathrm{S}_{\mathrm{a}}$ - value for varying values of $\mathrm{R}$. For subsequent values of $\mathrm{N}$ subsequent contour lines are determined the same way.

The contour line diagram for S355J0 steel, according to Heywood's formulae, is shown in Fig. 3 for $\mathrm{N}=10^{3}, 10^{4}, 10^{5}$, $10^{6}$ and $10^{7}$.
As results from Fig. 3 varying values of $\mathrm{S}_{\mathrm{m}}$ - stresses take place within the range $\left(-R_{m} ;+R_{m}\right)$, and those of $S_{a}$ - amplitudes within the range $\left(0 ; \mathrm{R}_{\mathrm{m}}\right)$. To the diagram are also introduced example lines corresponding with the directions of constant values of:

- cycle asymmetry ratio $(\mathrm{R}=$ const $)$

- cycle maximum stresses $\left(\mathrm{S}_{\max }=\right.$ const $)$

- cycle minimum stresses $\left(\mathrm{S}_{\min }^{\max }=\right.$ const $)$

- amplitude of stresses $\quad\left(\mathrm{S}_{\mathrm{a}}=\right.$ const $)$

- cycle mean stresses $\quad\left(\mathrm{S}_{\mathrm{m}}^{\mathrm{a}}=\right.$ const $)$.

Similar diagrams were elaborated on the basis of calculation results according to the models: I - (see Fig. 4), II - (Fig. 5), III - (Fig. 6), IV - (Fig. 7) and V - (Fig. 8).

From a general assessment of runs of diagram' s constant -value lines for the assumed values of $\mathrm{N}$, significant dfferences in the runs for the particular models can be observed.

For practical applications of the discussed models of two-parametric fatigue characteristics conformity of results of calculations and verifying tests is of fundamental importance.

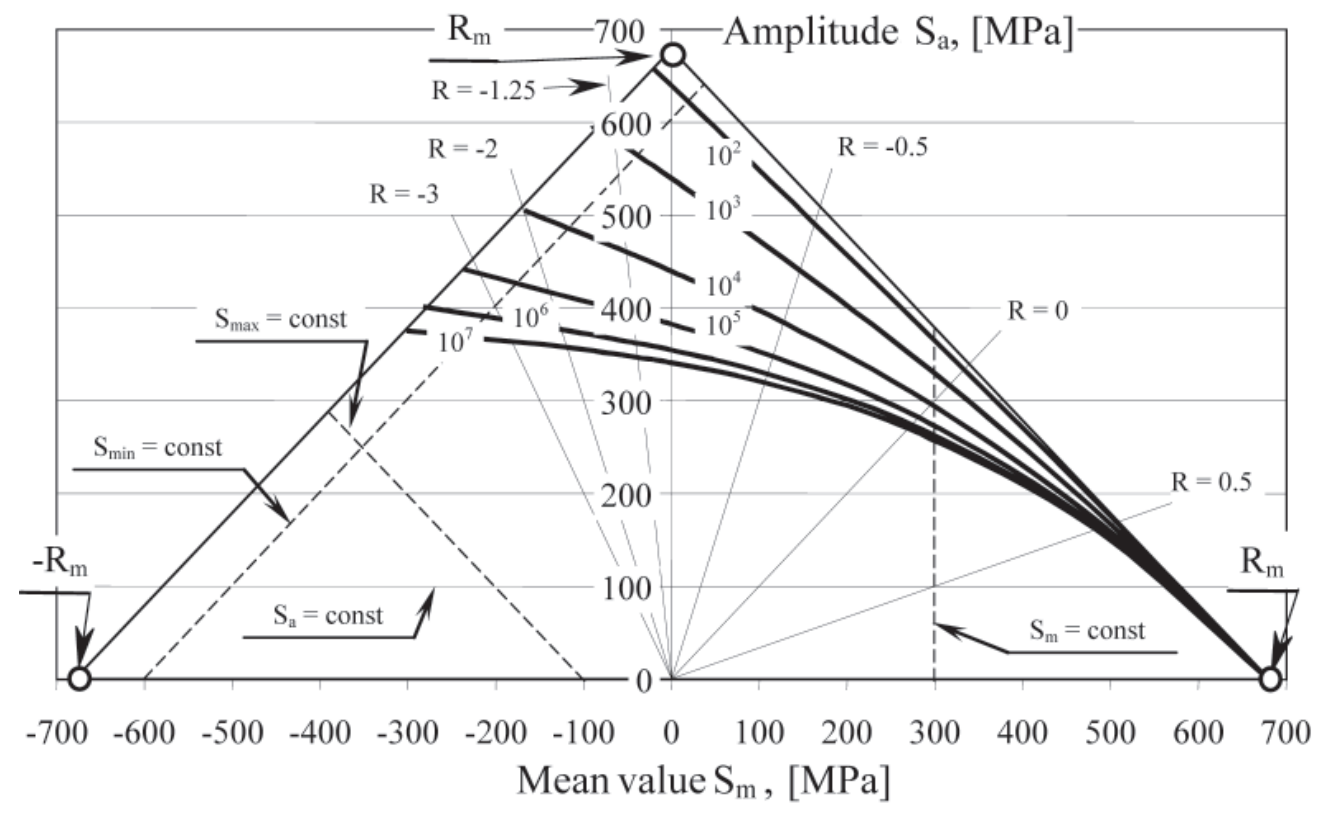

Fig. 3. Two-parametric fatigue diagram acc. Heywood's model (formula 4) for S355J0 steel

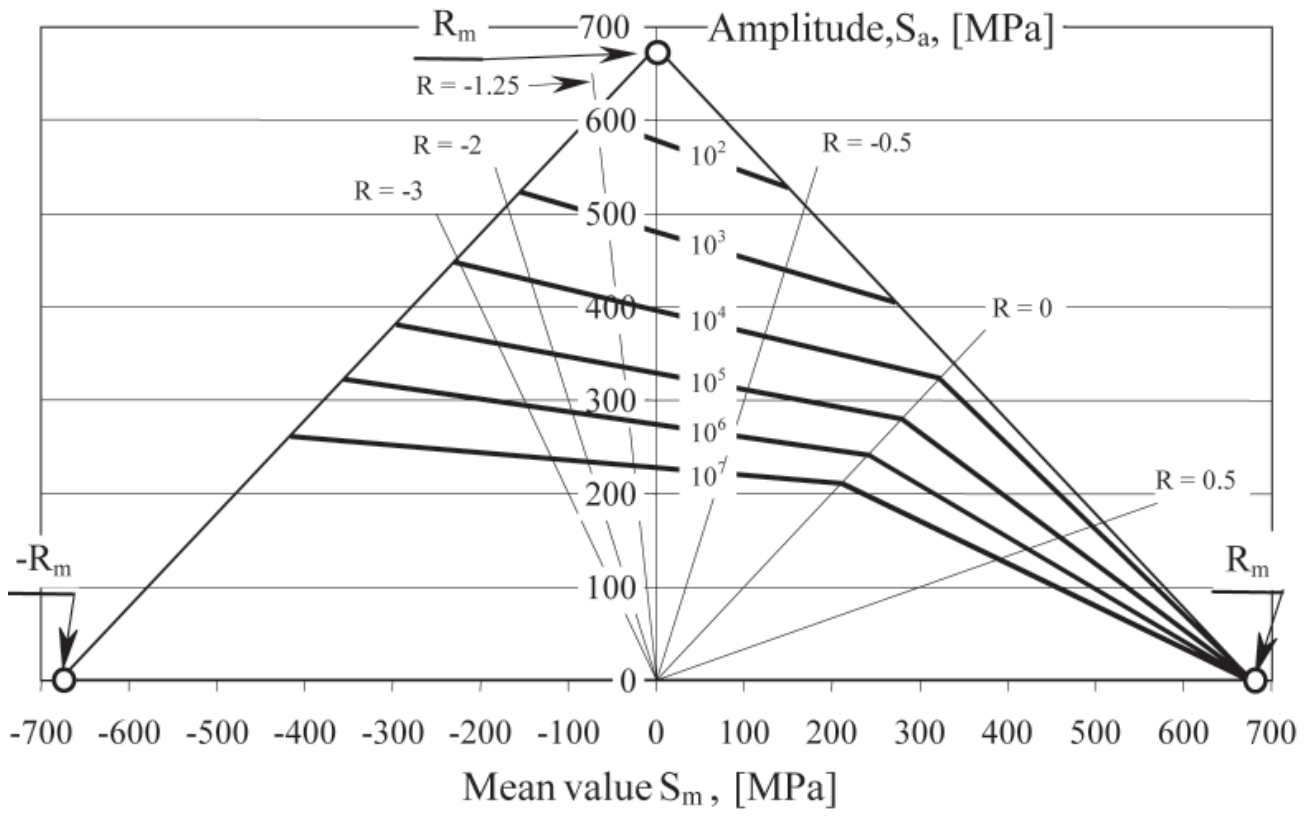

Fig. 4. Two-parametric fatigue diagram acc. Szala's model (formula 5 and 6) for S355J0 steel 


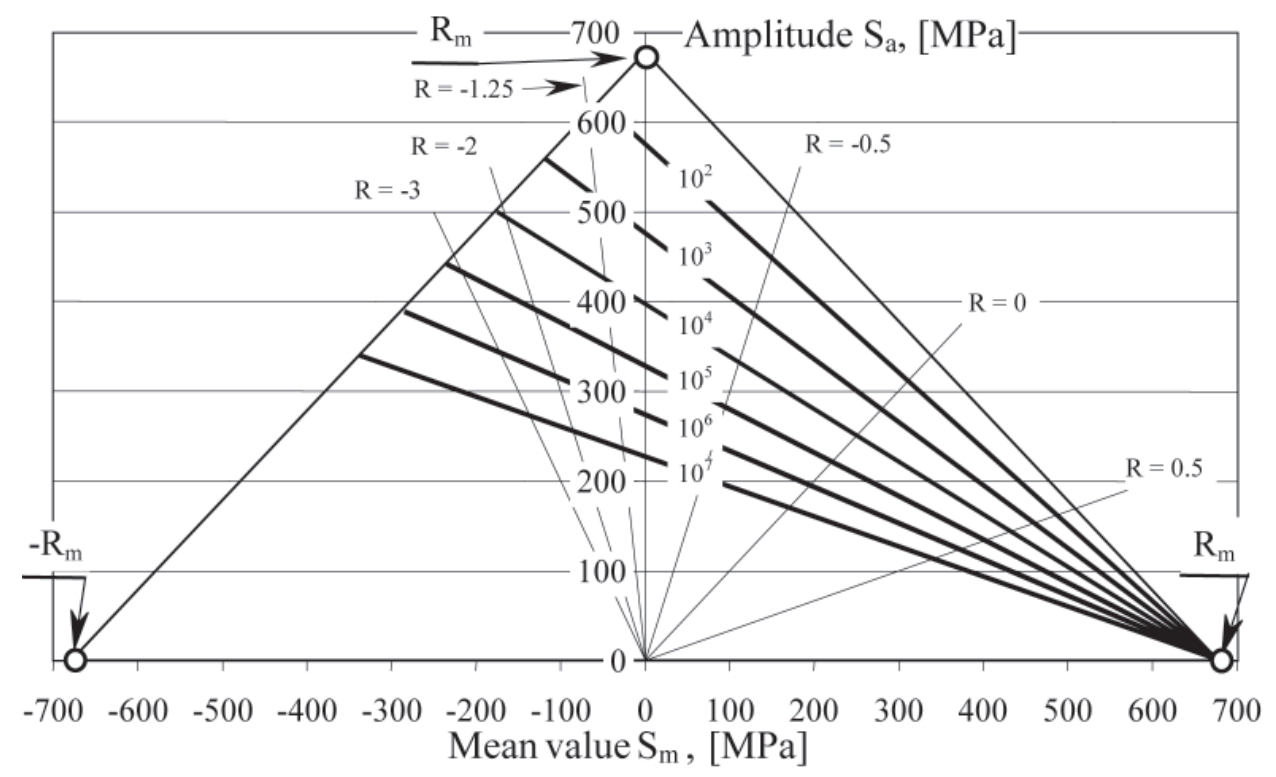

Fig. 5. Two-parametric fatigue diagram acc. Szala's model (formula 8) for S355J0 steel

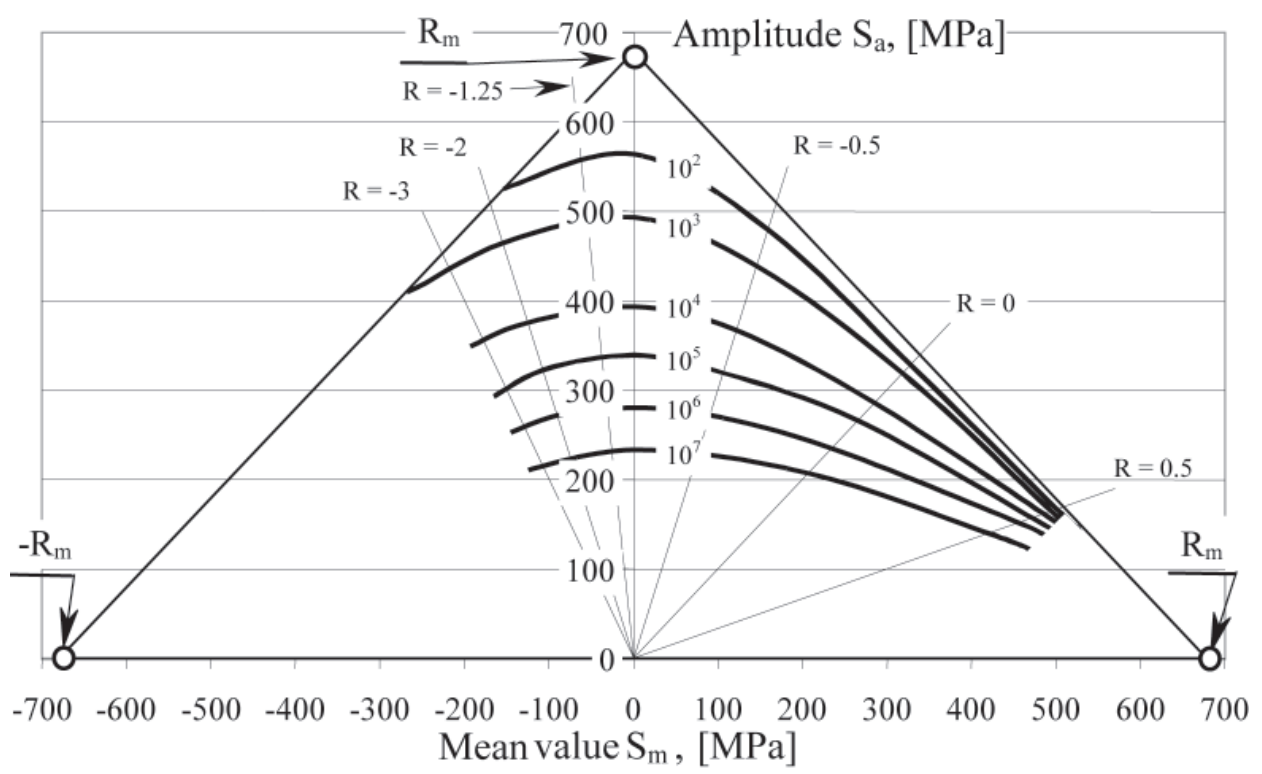

Fig. 6. Two-parametric fatigue diagram acc. Lipski's model (formula 9) for S355J0 steel

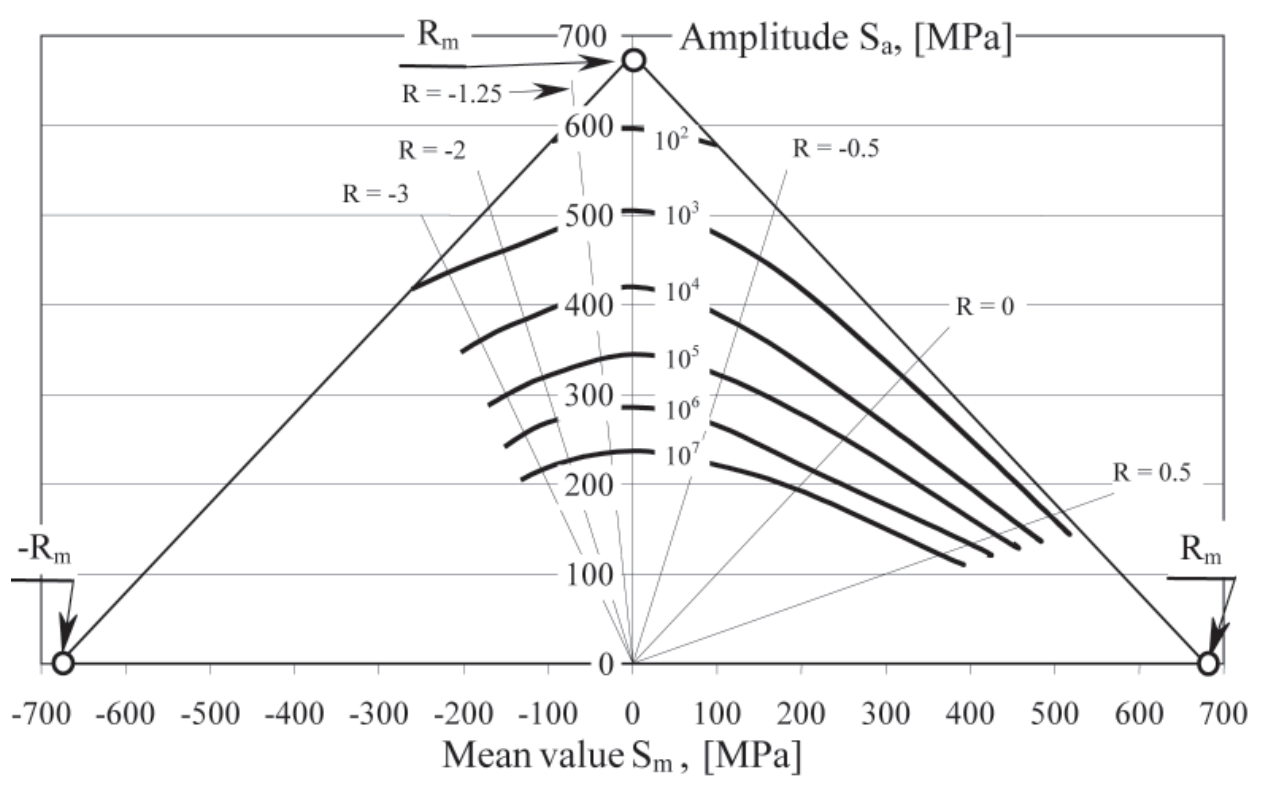

Fig. 7. Two-parametric fatigue diagram acc. Lipski's model IV (formula 10) for S355J0 steel 


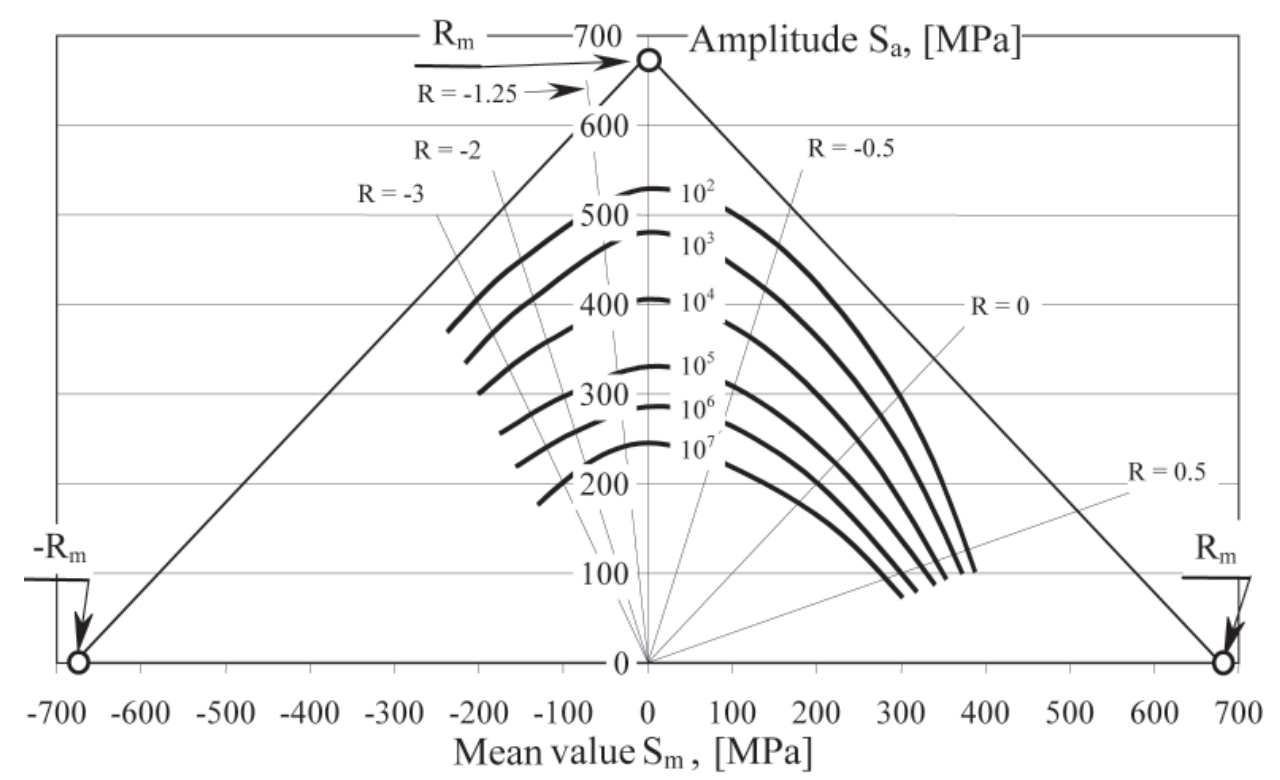

Fig. 8. Two-parametric fatigue diagram acc. Lipski's model V(formula 11) for S355J0 steel

\section{VERIFYING TESTS}

Quantitative analysis of conformity of results of calculations and verifying tests can be performed on the basis of comparison of Wöhler fatigue diagrams for definite values of the cycle asymmetry ratio $\mathrm{R}$. In this research the following values of $\mathrm{R}$ were assumed: $\mathrm{R}=0,5 ; 0 ;-0,5 ;-1,0 ;-1,25 ;-2,0$ and $-3,0$. The values cover to a large extent the parameter variability area of sinusoidal cycles, shown in Fig. 2.

Results of the experimental tests and Wöhler fatigue diagrams in the reference system $\mathrm{S}(\mathrm{N})$, determined on their basis for the above mentioned values of the cycle asymmetry ratio $\mathrm{R}$, are given in Fig. 9.The diagrams in the bi-logarithmic form are described by the equations (16):

$$
\log \mathrm{S}_{\mathrm{a}}=\mathrm{a} \log \mathrm{N}+\mathrm{b}
$$

Values of the parameter $\mathrm{a}$ and $\mathrm{b}$ are given in Tab. 4.

Data contained in Tab. 4 make it possible to present results of the tests in the form of a contour - line diagram of two-parameter fatigue characteristics (Fig. 10) similar to the diagrams based on results of calculations carried out in compliance with the analysed models (Fig. 3 through 8).

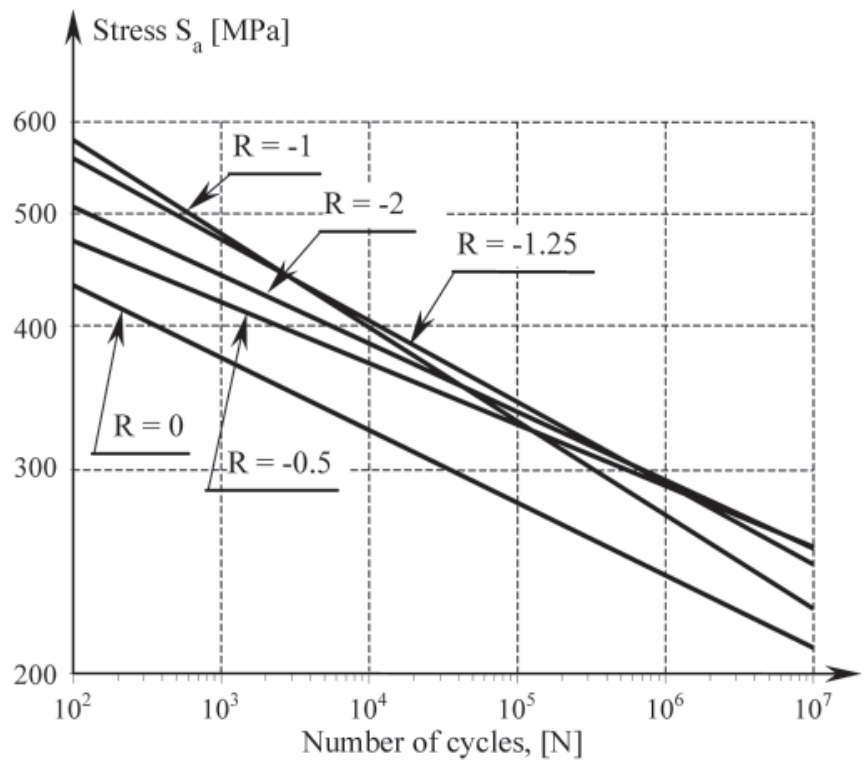

Fig. 9. Results of the fatigue tests and Wöhler fatigue diagrams determined on their basis, for the selected values of the cycle asymmetry ratio $R$

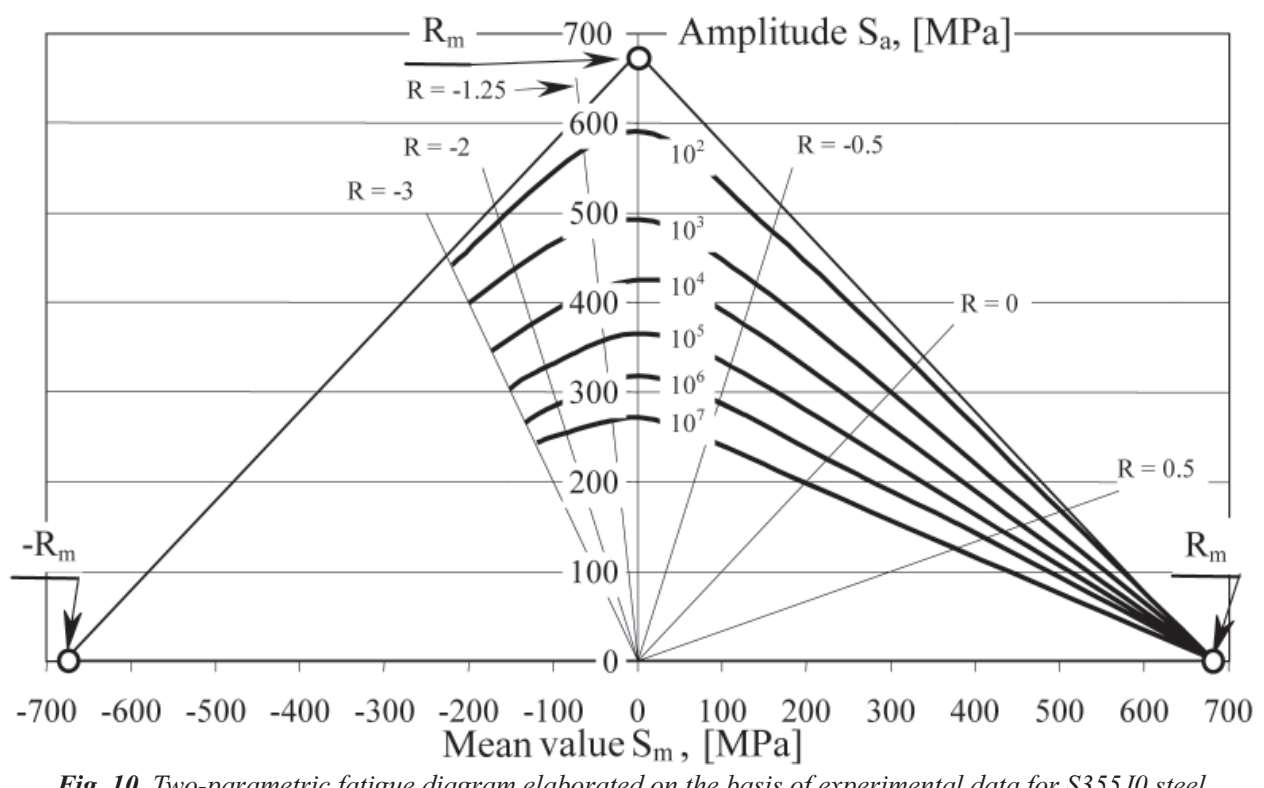

Fig. 10. Two-parametric fatigue diagram elaborated on the basis of experimental data for S355J0 steel 
Tab. 4. Values of the directional coefficient $a$ and the free term $b$ in the equations describing Wöhler fatigue diagram, for the assumed values of the cycle asymmetry ratio $R$

\begin{tabular}{|c|c|c|c|c|c|}
\hline \multirow{2}{*}{} & \multicolumn{5}{|c|}{ Cycle asymmetry ratio $\mathbf{R}$} \\
\cline { 2 - 6 } & 0 & -0.5 & -1.0 & -1.25 & -2.0 \\
\cline { 2 - 6 } & 1 & 2 & 3 & 4 & 5 \\
\hline $\mathbf{a}$ & -0.0628 & -0.0528 & -0.0811 & -0.0709 & -0.0592 \\
\hline $\mathbf{b}$ & 2.7630 & 2.7810 & 2.9247 & 2.8894 & 2.8233 \\
\hline
\end{tabular}

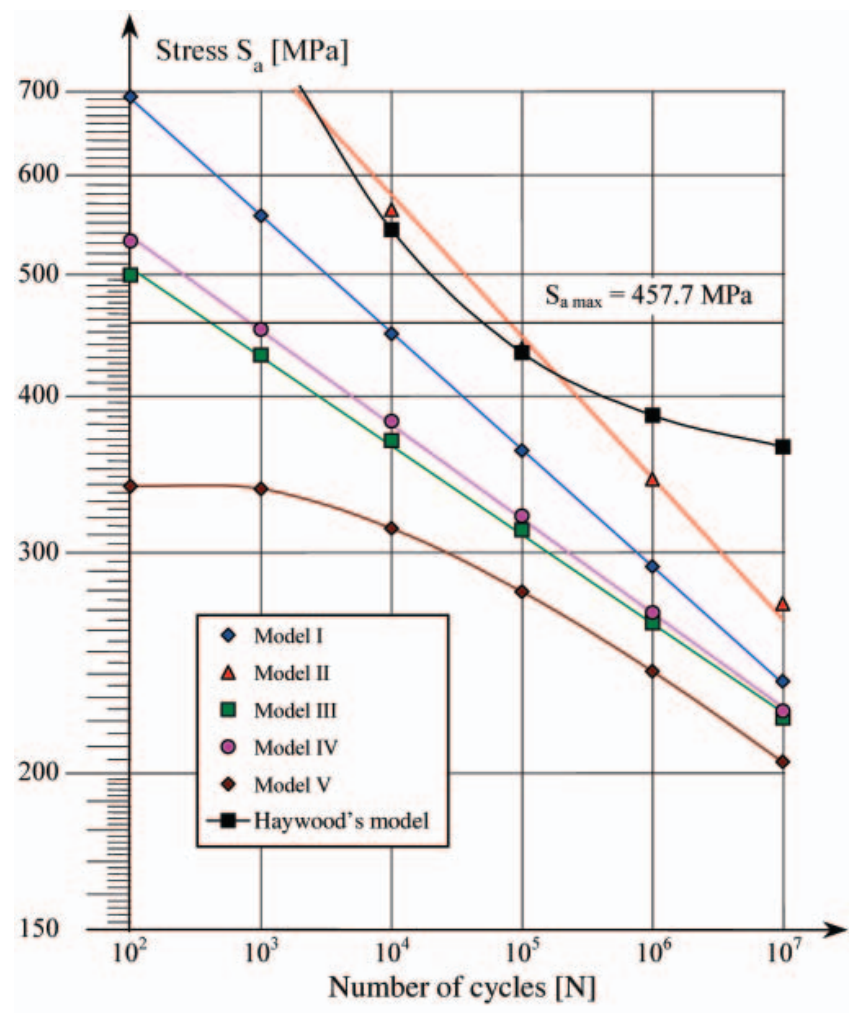

Fig. 11. Results of fatigue calculations according to the assumed models of two-parametric fatigue characteristics for $R=-3$

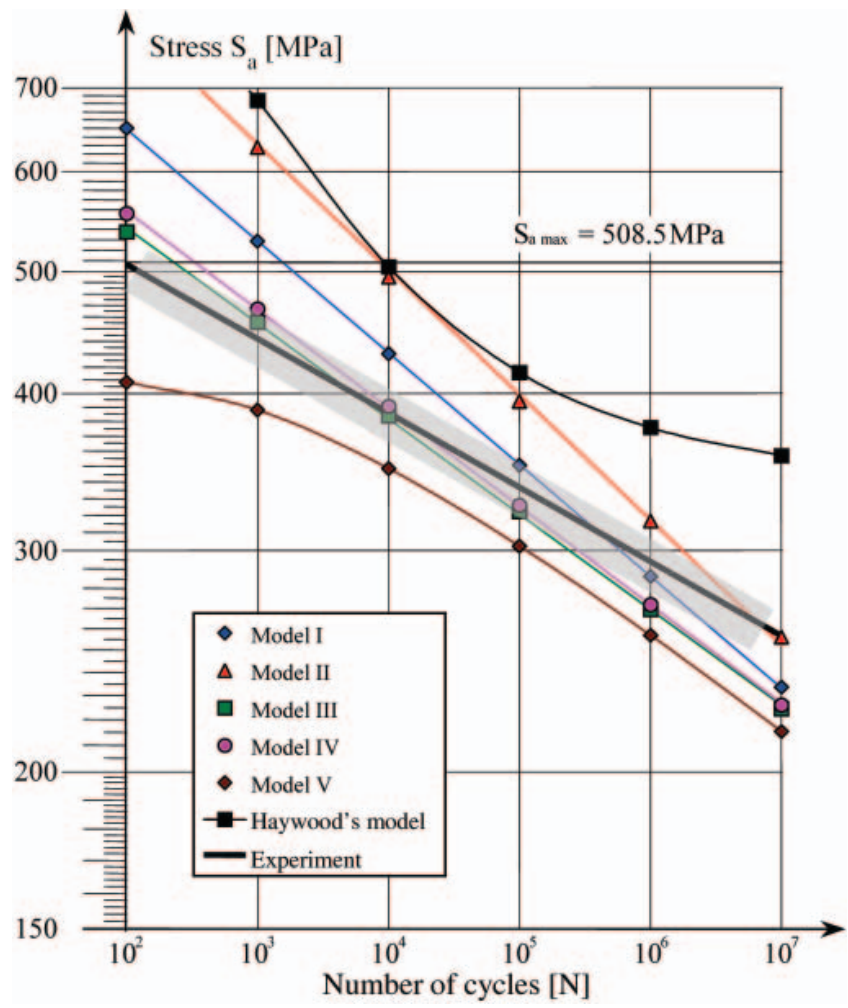

Fig. 12. Results of fatigue calculations according to the assumed models of two-parametric fatigue characteristics for $R=-2$
In the subsequent figures, Fig. 11 through 17, comparison is presented of calculation results obtained by using the selected models of two-parametric fatigue characteristics for the particular values of the cycle asymmetry ratio $\mathrm{R}$, with experimental test results. In Fig. 12 through 16 the calculation results are presented on the background of experimental diagrams. The shadowed zones indicate breadth of experimental data scatter bands. Moreover in the diagrams a maximum value of $\mathrm{S}_{\max }$ complying with the condition $\mathrm{S}_{\max }<\mathrm{R}_{\mathrm{m}}$, is given.

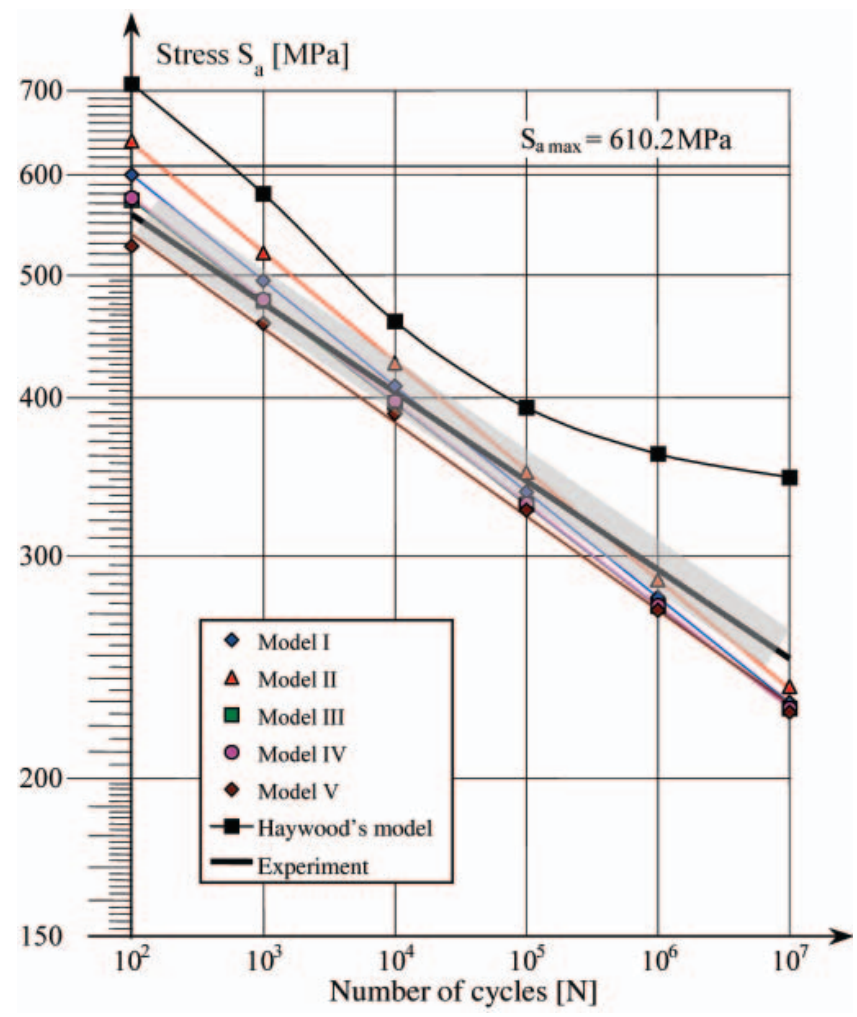

Fig. 13. Results of fatigue calculations according to the assumed models of two-parametric fatigue characteristics for $R=-1.25$

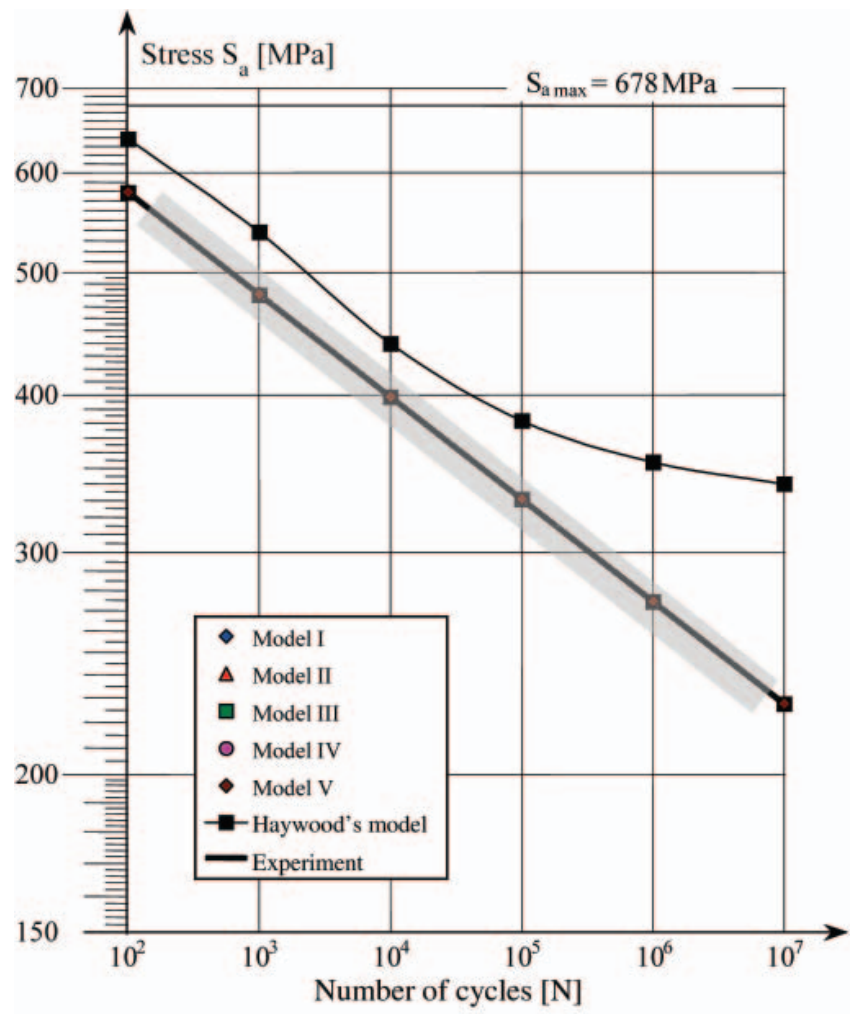

Fig. 14. Results of fatigue calculations according to the assumed models of two-parametric fatigue characteristics for $R=-1.0$ 
In Fig. 11 (for $\mathrm{R}=-3$ ) and in Fig. 17 (for $\mathrm{R}=0.5$ ) the experimental fatigue diagrams were determined by extrapolating the test results for the range of $\mathrm{R}(-2,0 ; 0)$.

From overall assessment of the data shown in Fig. 1 through 17 result differences between values of the calculated stress amplitudes $\mathrm{S}_{\mathrm{ac}}$ and those obtained from tests, $\mathrm{S}_{\mathrm{ex} \text { a }}$,

depending on an assumed calculation model, assumed value of fatigue life $\mathrm{N}$ and values of the cycle asymmetry ratio $R$.

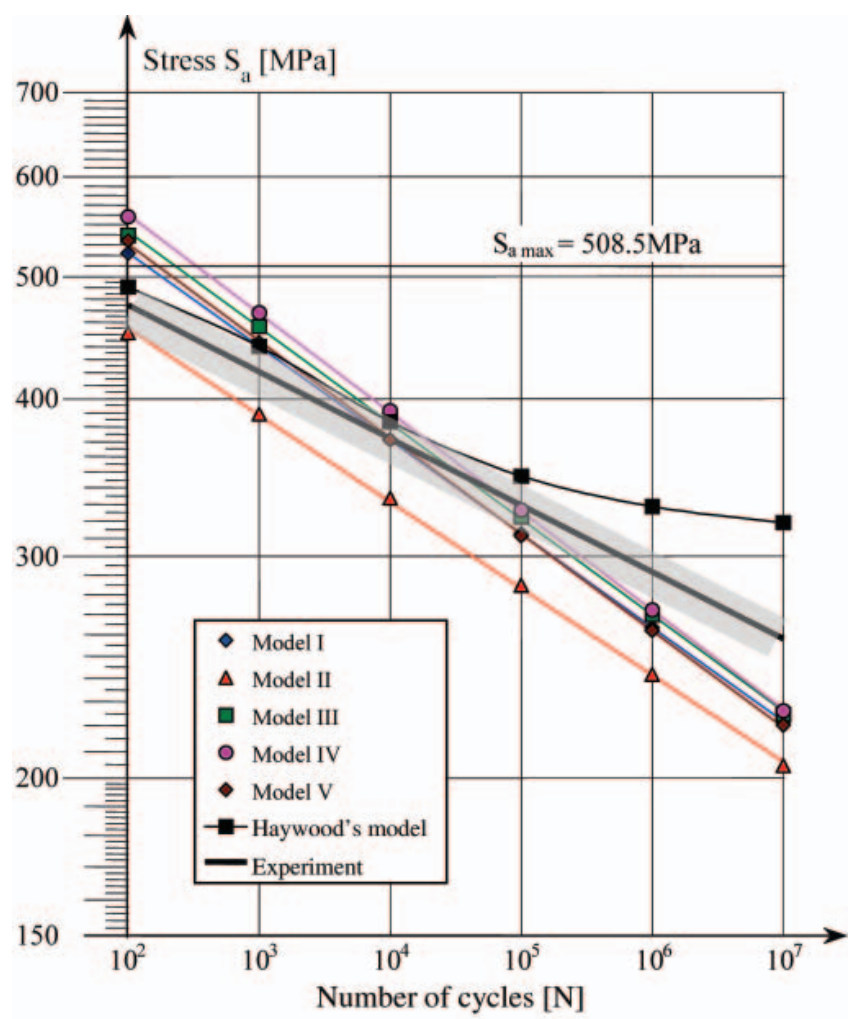

Fig. 15. Results of fatigue calculations according to the assumed models of two-parametric fatigue characteristics for $R=-0.5$

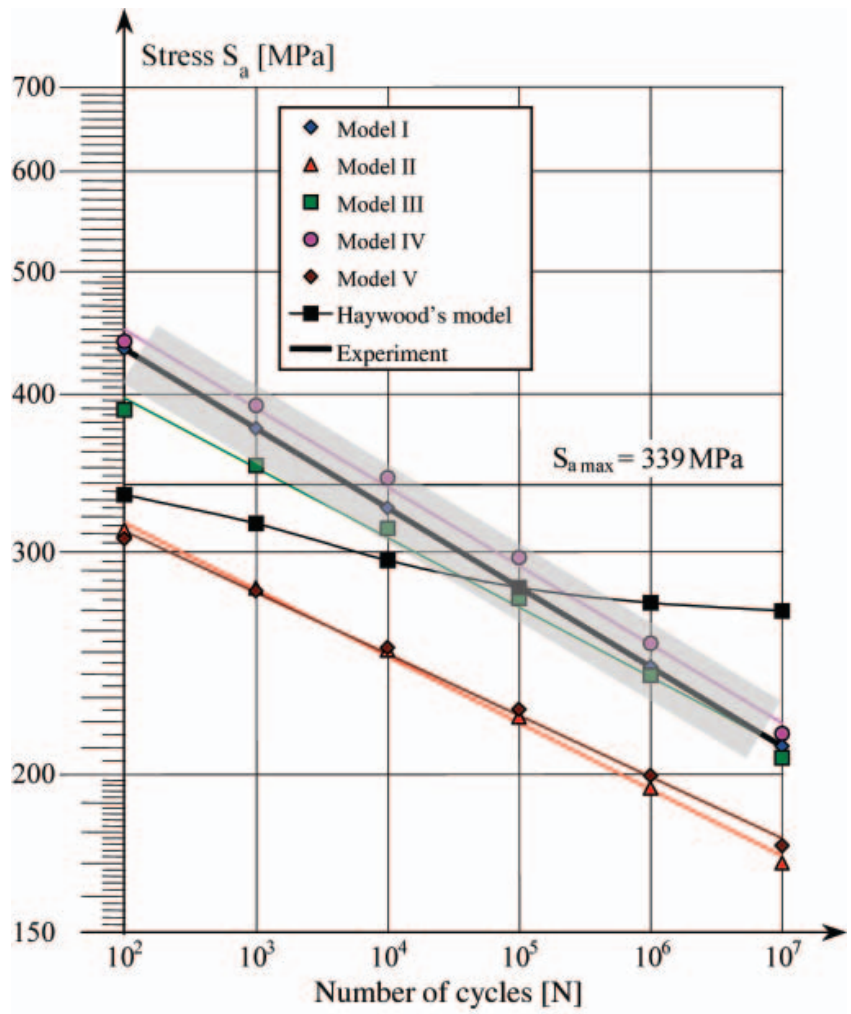

Fig. 16. Results of fatigue calculations according to the assumed models of two-parametric fatigue characteristics for $R=0$

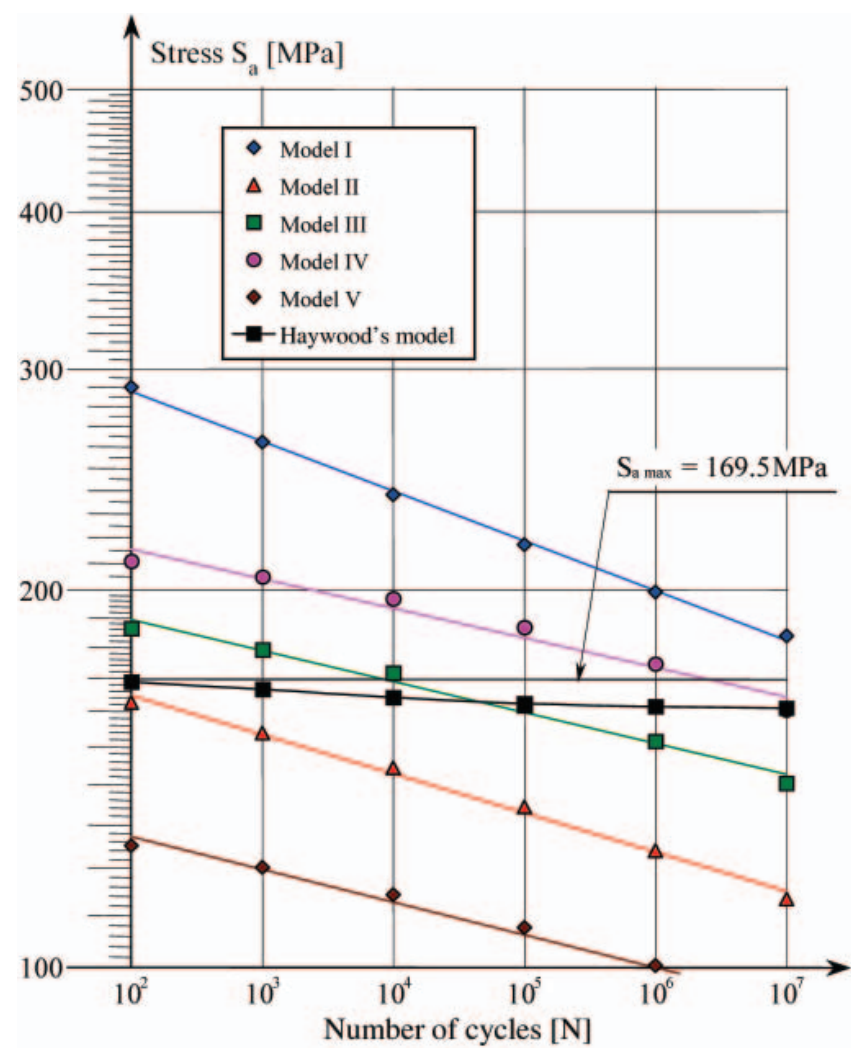

Fig. 17. Results of fatigue calculations according to the assumed models of two-parametric fatigue characteristics for $R=0.5$

\section{ANALYSIS OF THE CALCULATION AND TEST RESULTS}

Differences between results of calculations of $S_{\mathrm{ac}}$ and results of tests of $\mathrm{S}_{\text {ex a }}$ related to amplitude values depend on a model of assumed values of the fatigue life $\mathrm{N}$ and cycle asymmetry ratio $\mathrm{R}$, taken for calculations.

The relative differences, $\delta$, between results of calculations and tests, determined according to the formula (17):

$$
\delta=\frac{\mathrm{S}_{\mathrm{ac}}-\mathrm{S}_{\mathrm{a} \text { ex }}}{\mathrm{S}_{\mathrm{a} \text { ex }}} \cdot 100 \%
$$

are presented in the form of bar diagrams in the successive figures as follows: for the Heywood' s model - in Fig.18, model I - Fig.19, model II - Fig. 20, model III - Fig. 21, model IV- Fig. 22 and model V - Fig. 23. Within the entire variability range of the fatigue life $\mathrm{N}$ and cycle asymmetry ratio $\mathrm{R}$ the largest differences appear in the Heywood's model $(\mathrm{H})$, and in the extreme cases they reach values from $+49.32 \%$ to $-23.21 \%$. The largest differences occur for high values of fatigue life $\left(\mathrm{N}=10^{5} \div 10^{7}\right)$. The interval corresponds with stress values observed in the cycles of a significant share in service load spectra of structural elements. The fact greatly affects fatigue calculations whose aim is to assess serviceability of structural elements.

The above mentioned dif ferences result from that the Heywood's model was based on the data of material strength properties obtained from monotonic tension tests.

In the remaining models material properties are represented by the fatigue life determined either from the test under oscillating load $(\mathrm{R}=-1)$ - in the case of the models: II, III, IV and $\mathrm{V}$, or the test under oscillating load $(\mathrm{R}=-1)$ and pulsating load $(\mathrm{R}=0)$ - in the case of the model I. Therefore the calculation results according to the above mentioned models for values of $\mathrm{R}=-1$, and additionally to the model $\mathrm{I}$ for $\mathrm{R}=0$, are in full conformity with the test results, that is obvious and in particular diagrams marked: $\delta=0$. 
Out of all the analyzed models for the entire range of fatigue life $\mathrm{N}$ and cycle asymmetry ratio $\mathrm{R}$ the calculations according to the models: I, III and IV showed the greatest conformity with the experiment.

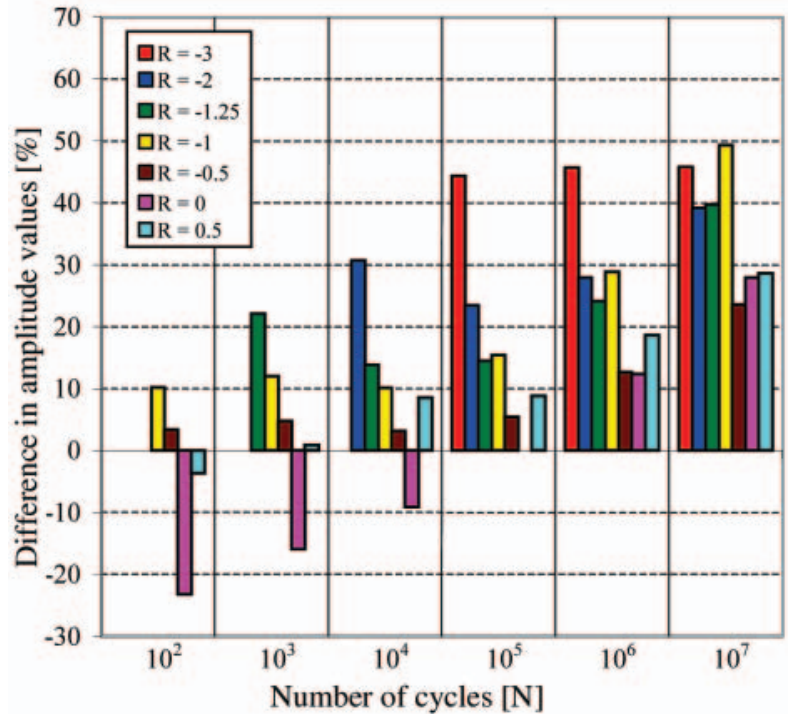

Fig. 18. Diagram showing difference in amplitude values determined with the use of Heywood's model

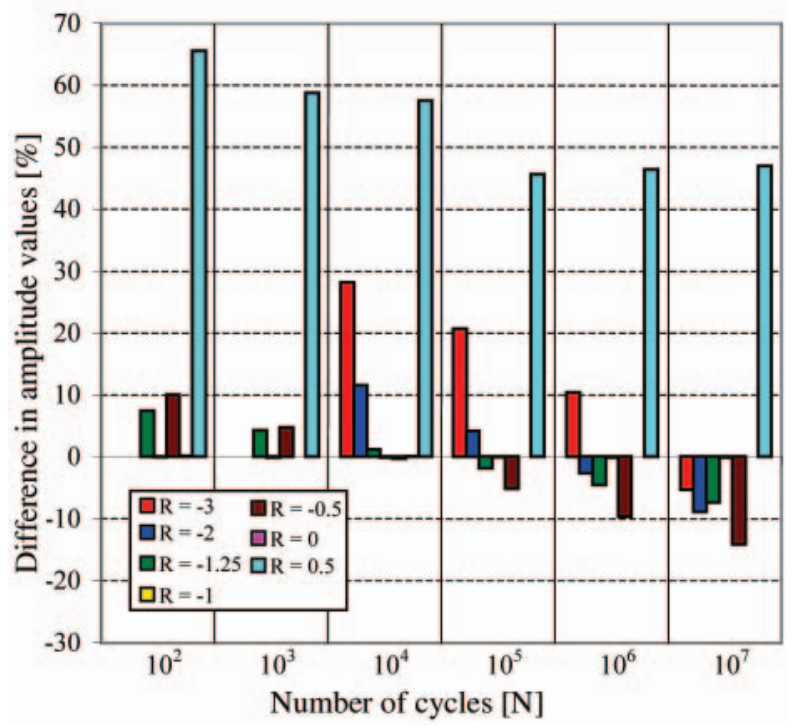

Fig. 19. Diagram showing difference in amplitude values determined for the model I

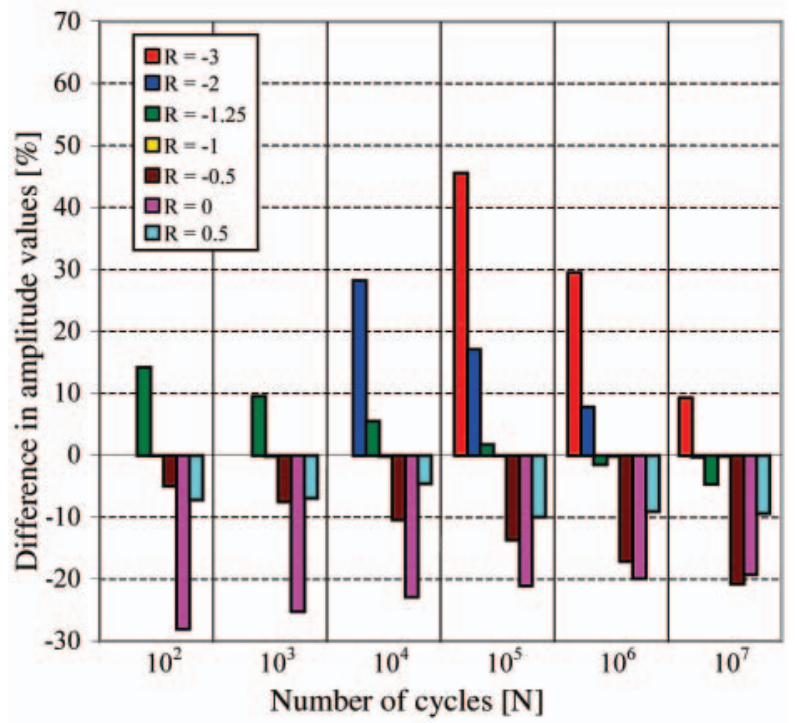

Fig. 20. Diagram showing difference in amplitude values determined for the model II
In the case of the model I the calculations for $\mathrm{R}=0.5$ constitutes an exception, whose discrepancies from test results reached about $65 \%$ for $\mathrm{N}=10^{2}$.

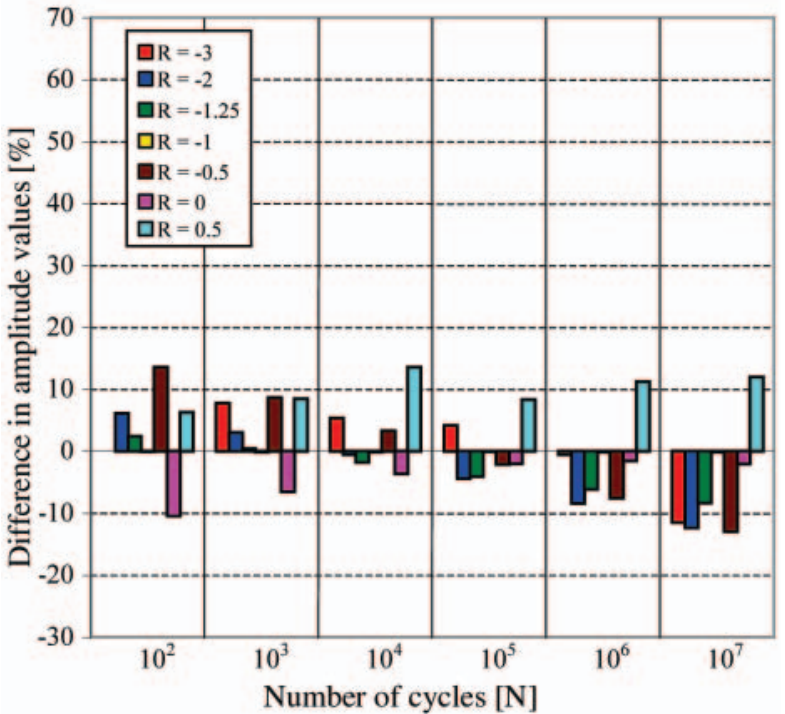

Fig. 21. Diagram showing difference in amplitude values determined for the model III

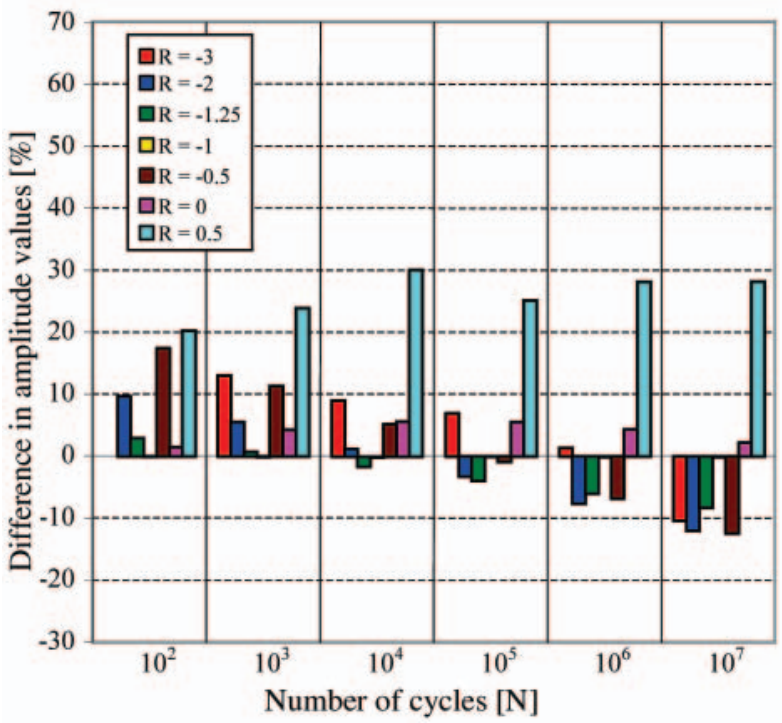

Fig. 22. Diagram showing difference in amplitude values determined for the model $\mathrm{IV}$

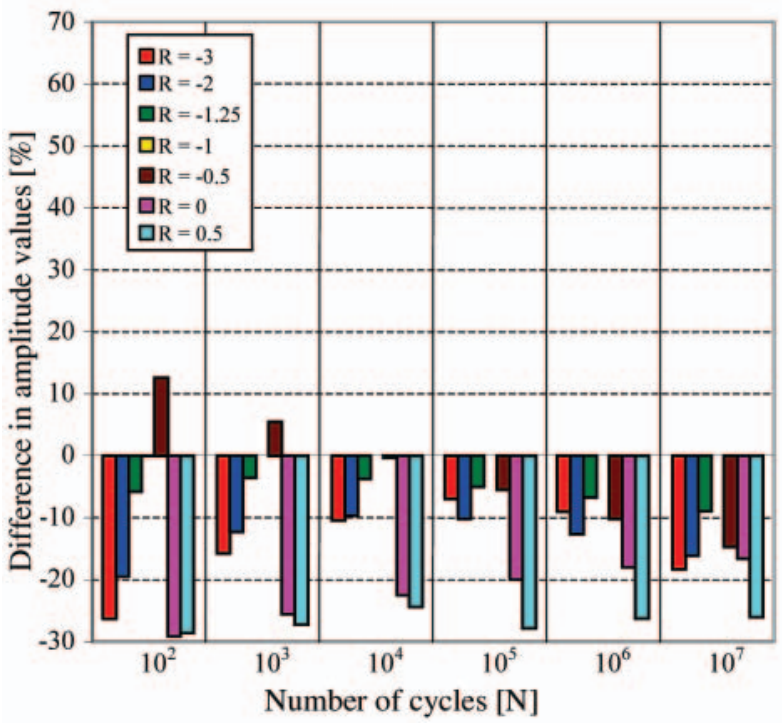

Fig. 23. Diagram showing difference in amplitude values determined for the model $V$ 
The model I is sensitive to magnitude of the factor of material sensitivity to cycle asymmetry, $\psi_{\mathrm{N}}$. In the case of the results shown in Fig. 19 the calculations were carried out with the use of $\psi_{N}$ - value determined from Eq. (7), Tab. 1. Data for the calculations were taken from Wöhler diagrams for the load variability ratios: $R=-1$ and $R=0$. The large scatter of fatigue test results on the basis of which the diagrams were determined, makes accuracy of determination of the factor $\psi_{\mathrm{N}}$ from Eq. (7), low.

By modifying the model I with regard to magnitude of the factor $\psi_{\mathrm{N}}$, conformity between calculations performed for the model and appropriate experimental data can be greatly improved.

\section{CONCLUSIONS}

From the above presented analysis the following results:

a) conformity between calculation results and fatigue test results greatly depends on assumed two-parametric fatigue characteristics

b) within the entire range of the analysis the highest conformity was obtained for the models: I, III, IV, and the lowest - for Heywood's model

c) the low conformity of calculations according to Heywoods model results from the assumption of the tensile strength $\mathrm{R}$ as a quantity characterizing properties of material subjected to cyclic loads

d) the higher conformity of calculation results according to the remaining models: I throughV, results from the assumption of Wöhler fatigue diagram parameters as characteristics of material mechanical properties; such data for a variety of materials can be obtained from tests or literature sources of different kind, e.g. [16, 17]

e) for preliminary calculations, e.g. structural design process in which precise data on material cyclic properties and service loads are not yet known, the simple models I and II are recommended

f) for further considerations an analysis of influence of the differences in two-parametric fatigue characteristics described in this paper, on calculation results of fatigue life in conditions of service load spectra, is of a great importance

g) as results from literature data, especially those contained in [7], the above described models can yield dif ferent conformity with results of tests of other materials, the opinion is confirmed by the paper [12] devoted to tests of aircraft Al-alloys

h) another important problem is determining range of application of the described models to high-cycle fatigue (HCF), which requires determining an area of twoparametric fatigue characteristics in compliance with the assumed criterion [17]; as the criterion $\mathrm{S}_{\max } \leq \mathrm{R}_{\mathrm{e}}$, commonly met in the subject-matter literature, is considered approximate and ineffective in some cases

i) a seperate problem important from the point of view of practical applications is description of two-parametric fatigue characteristics for notched elements.

The problems specified in the points: f), g), h), i) will be discussed in next papers.

\section{NOMENCLATURE}

A - $\quad$ elongation [\% ]

C - constant in the formula describing Wöhler fatigue diagram for off-zero pulsating load $(\mathrm{R}=0)$

$\mathrm{C}_{0}-$ constant in the formula describing Wöhler

- cycle number - general notation (fatigue life)

- cycle number - fatigue life corresponding

$\begin{array}{ll}\mathrm{N}_{0} & \text { - cycle number }- \text { fatig } \\ \mathrm{R}=\mathrm{S}_{\min } / \mathrm{S}_{\max } & \text { - cyith fatigue limit } \\ \text { - cysymmetry ratio }\end{array}$

$\mathrm{R}=\mathrm{S}_{\min } / \mathrm{S}_{\max } \quad-$ material yield point [MPa]

$\mathrm{R}_{\mathrm{f}}$ - fatigue limit - general notation [MPa]

$\mathrm{R}_{\mathrm{m}} \quad-$ material tensile strength [MPa]

$\mathrm{R}_{0}^{\mathrm{m}} \quad$ - fatigue limit under pulsating load $(\mathrm{R}=0)$ for $\mathrm{N}_{0}$ cycle number, [MPa]

$\mathrm{R}_{0}^{\mathrm{N}} \quad$ - fatigue strength under sinusoidal pulsating load $(\mathrm{R}=0)$ for $\mathrm{N}$ cycle number, $[\mathrm{MPa}]$

$\mathrm{R}_{-1} \quad$ - fatigue limit under oscillating load $(\mathrm{R}=-1)$ for $\mathrm{N}_{0}$ cycle number, $[\mathrm{MPa}]$

$\mathrm{R}_{-1}^{\mathrm{N}} \quad$ - fatigue strength under sinusoidal oscillating load $(\mathrm{R}=-1)$ for $\mathrm{N}$ cycle number, [MPa]

$\begin{array}{ll}\mathrm{S} & - \text { specimen stress }- \text { general notation, [MPa] } \\ \mathrm{S}_{\mathrm{a}}=0,5\left(\mathrm{~S}_{\max }-\mathrm{S}_{\min }\right) & - \text { sinusoidal cycle stress amplitude [MPa ] }\end{array}$

$\mathrm{S}_{\mathrm{m}}=0,5\left(\mathrm{~S}_{\max }+\mathrm{S}_{\text {min }}\right)-$ mean sinusoidal cycle stress $[\mathrm{MPa}]$

$\mathrm{S}_{\max } \quad-$ maximum sinusoidal cycle stress [MPa ]

$\mathrm{S}_{\min }-\quad-$ minimum sinusoidal cycle stress [MPa ]

$\mathrm{Z}_{-} \quad$ contraction [\%]

$\mathrm{m} \quad-$ exponent in formula describing Wöhler fatigue diagram for pulsating load $(\mathrm{R}=0)$

- exponent in formula describing Wöhler fatigue diagram for oscillating load $(\mathrm{R}=-1)$

- factor of material sensitivity to cycle asymmetry, for $\mathrm{N}=\mathrm{N}_{0}$

$\psi_{\mathrm{N}} \quad$ - factor of material sensitivity to cycle asymmetry, for $\mathrm{N} \neq \mathrm{N}_{0}$.

\section{BIBLIOGRAPHY}

1. Bendat J.S., Pierdol A.G.: Methods of analysis and measurement of random signals (in Polish), PWN, Warszawa, 1976

2. Szala J., Boroński D.: Assessment of material fatigue state in diagnostics of machines and devices, Chapter 9 (in Polish). Wydawnictwo Instytutu Technologii Eksploatacji - Państwowego Instytutu Badawczego (Publishing House of Operation Technology Institute - State Research Institute), Bydgoszcz, 2008

3. Kocak M. (Editor), Webster S., Janosch J.J., Ainsworth R.A., Koers R.: FITNET - Fitness - for - Service Procedure, Final Draft MK7, 2006

4. Kocańda S., Szala J.: Background for fatigue calculations (in Polish). PWN, Warszawa, 1997

5. Fricke W., Petershagen H., Paetzold H.: Fatigue Strength of Ship Structures - Part I: Basic Principle. Information from Germanischer Lloyd Group, 1, Hamburg, 1997

6. Fricke W., Petershagen H., Paetzold H.: Fatigue Strength of Ship Structures - Part II: Examples. Information from Germanischer Lloyd Group, 1, Hamburg, 1998

7. Figge I.E.: An Empirical Equation Relating Fatigue Limit and Mean Stress. NASA Technical Note D-3883, Washington, 1967

8. Heywood R.B.: Designing Against Fatigue. Chapman Hall, London, 1962

9. Szala J.: Tests and calculations of machine elements under random and programmed loads (in Polish). Instytut Podstawowych Problemów Techniki, PAN (Institute of Fundamental Engineering Problems, Polish Academy of Sciences), Warszawa, 1979

10. Szala J., Szala G.: Two-parametric fatigue characteristic - formulating problem. Problemy Eksploatacji 3/2001(42), Wydawnictwo Instytutu Technologii Eksploatacji (Publishing House of Operation Technology Institute), Radom, 2001. 
11. Szala J., Szala G.: Comperative analyses of two-parametric fatigue characteristic and their experimental verification. Problemy Eksploatacji 3/2001(42), Wydawnictwo Instytutu Technologii Eksploatacji (Publishing House of Operation Technology Institute), Radom, 2001

12. Szala J., Lipski A.: A concept of description of material fatigue properties for fatigue life calculations of structural elements (in Polish). Zagadnienia Eksploatacji Maszyn (Problems of Operation of Machines), Quarterly of KBM PAN, Bulletin 2 (142), 2005

13. Bołotin W.W.: Statistical methods applied to mechanics of structures (in Polish). Wydawnictwo Arkady (Arkady Publishing House), Warszawa, 1968

14. Collins J.A.: Failure of Materials in Mechanical Design, Analysis, Prediction, Prevention. John Wiley \& Sons Inc., 1993

15. Howard E. Boyer (Editor): Atlas of Fatigue Curves. ASM International, The Materials Information Society, Fifth printing, August, 2003
16. Трощенко В.Т., Сосновский Л.А.: Сопротивление усталости металлов и сплавов. Киев, Наукова Думка, 1987

17.Szala G. Ligaj B.: Evaluation criteria of low- and high-cycle fatigue in fatigue life calculations of constructional elements. Logistyka, No. 6, 2009

Note: This work has been elaborated in the frame of the project No. 0715/B/T02/2008/35 financed by Polish Ministry of Sciences and Higher Education.

\section{CONTACT WITH THE AUTHORS}

Bogdan Ligaj, Ph. D., Grzegorz Szala, Ph. D.

Faculty of Mechanical Engineerig, University of Technology and Life Science, Prof. S. Kaliskiego 7

85-763 Bydgoszcz, POLAND e-mail: bogdanj@utp.edu.pl 